\title{
Taksiran Matriks Teknologi untuk Menentukan Sektor Unggulan di Suatu Wilayah Menggunakan Metode RAS
}

\section{Hana Mumtaz ${ }^{*}$ Icih Sukarsih}

Prodi Matematika, Fakultas Matematika dan Ilmu Pengetahuan Alam, Universitas Islam Bandung, Indonesia.

*hanamumtaz45@gmail.com, sukarsh75@gmail.com

\begin{abstract}
The economy of a region consists of various interrelated sectors. The linkages between sectors can be analyzed to determine which sectors have a high contribution rate to the economy of a region or are referred to as leading sectors. Determination of the leading sector for a particular year can be done through input-output analysis. The input-output tables used to analyze the leading sectors are not published every year, so the input-output tables for a particular year are sometimes obtained through the estimation method. There is technical coefficient matrix in the input-output table which states the total input ratio for a sector to the total output of other sectors. This study aims to estimate the technical coefficient matrix in Tegal Regency in 2020 using the RAS method. The estimation is based on the input-output table of Tegal Regency in 2016. The results of the technical coefficient matrix estimation are used to create a multiplier matrix which then analyzed to determine the leading sectors by calculating the dispersion power index and the sensitivity index of each sector. Based on analysis, it was found that the manufacturing sector and the construction sector are the leading sectors in the Tegal Regency area in 2020 .
\end{abstract}

Keywords: Leading Sector, Input-output Analysis, RAS Method.

Abstrak. Perekonomian suatu wilayah terdiri dari berbagai sektor yang saling terkait. Keterkaitan antar sektor dapat dianalisis untuk menentukan sektor yang memiliki tingkat kontribusi tinggi dalam perekonomian suatu wilayah atau disebut sebagai sektor unggulan. Penentuan sektor unggulan untuk tahun tertentu dapat dilakukan melalui analisis input-output. Tabel input-output yang digunakan untuk menganalisis sektor unggulan tidak dipublikasikan setiap tahun, sehingga tabel input-ouput pada tahun tertentu terkadang diperoleh melalui metode penaksiran. Dalam suatu tabel input-output terdapat matriks teknologi yang menyatakan rasio jumlah output suatu sektor yang diperlukan sebagai input untuk menghasilkan satu unit output pada sektor lain. Penelitian ini bertujuan untuk menaksir matriks teknologi di Kabupaten Tegal tahun 2020 menggunakan metode RAS. Penaksiran tersebut didasarkan pada tabel input-output Kabupaten Tegal tahun 2016. Hasil taksiran matriks teknologi digunakan untuk membuat matriks pengganda yang selanjutnya dianalisis untuk menentukan sektor unggulan dengan menghitung indeks daya penyebaran dan indeks derajat kepekaan setiap sektor. Berdasarkan hasil analisis diperoleh bahwa sektor industri pengolahan dan sektor konstruksi merupakan sektor unggulan wilayah Kabupaten Tegal pada tahun 2020.

Kata Kunci: Sektor Unggulan, Analisis Input-output, Metode RAS 


\section{A. Pendahuluan}

Ekonomi adalah ilmu tentang asas-asas produksi, distribusi, dan pemakaian barang-barang serta kekayaan [1]. Dalam kajian ilmu ini dipelajari banyak hal mengenai kebutuhan, permintaan dan penawaran suatu barang produksi. Para ahli menyatakan bahwa keilmuan ini dapat disajikan dan dimodelkan secara matematis, baik dalam perhitungan, prediksi, serta penggambaran ke dalam bentuk grafik yang mudah dipahami.

Dalam sistem ekonomi yang terdiri dari beberapa sektor, setiap sektor ekonomi saling berkaitan. Hal ini dikarenakan masing-masing sektor membutuhkan input berupa bahan baku maupun bahan penolong yang diperoleh dari sektor lain untuk dapat memproduksi output berupa barang ataupun jasa. Keterkaitan antar sektor dapat dianalisis sehingga dapat ditentukan sektor yang memiliki tingkat kontribusi yang tinggi atau sektor unggulan di suatu wilayah.

Sektor unggulan merupakan sektor yang memiliki kemampuan tinggi dalam menggerakkan perekonomian sehingga dapat dijadikan sebagai tumpuan harapan pembangunan ekonomi [2]. Sektor yang menjadi sektor unggulan di suatu wilayah tidak besifat tetap. Hal ini dapat disebabkan oleh berbagai faktor, diantaranya adalah menurunnya permintaan dari daerah lain atau berkurangnya sumber daya yang tersedia di wilayah tersebut. Untuk mengetahui sektor unggulan di suatu wilayah pada tahun tertentu dapat dilakukan melalui analisis input-output.

Analisis input-output merupakan suatu analisis perekonomian dengan melihat keterkaitan antar sektor ekonomi secara menyeluruh [3]. Analisis input-output pertama kali diperkenalkan oleh Wassily Leontief pada tahun 1930-an. Analisis ini didasarkan pada suatu tabel input-output (tabel I-O) yang menggambarkan transaksi barang dan jasa antar sektor perekonomian. Tabel input-output diperoleh dari hasil survei terhadap seluruh sektor ekonomi. Hal ini menyebabkan perolehannya memerlukan waktu yang tidak singkat dan dana yang relatif besar. Sehingga, tabel input-output suatu wilayah tidak dipublikasikan setiap tahun.

Dalam suatu tabel input-output terdapat matriks teknologi yang menyatakan rasio jumlah output suatu sektor yang diperlukan sebagai input untuk menghasilkan satu unit output pada sektor lain. Pada rentang waktu pubilkasi, diasumsikan matriks teknologi tidak mengalami perubahan. Namun koefisien matriks teknologi dapat dipengaruhi oleh beberapa faktor, diantaranya adalah perubahan harga dan klasifikasi yang digunakan. Akibatnya dikembangkan suatu metode untuk menaksir suatu matriks teknologi pada tahun tertentu tanpa harus melakukan survei [4].

Penaksiran matriks teknologi dapat dilakukan dengan menggunakan metode RAS. Metode ini pertama kali diperkenalkan oleh Richard Stone pada tahun 1961. Penaksiran matriks teknologi tahun tertentu menggunakan metode RAS didasarkan pada suatu matriks teknologi hasil survei yang telah ada sebelumnya. Metode RAS memiliki algoritma sederhana yang menjamin tidak ada nilai negatif yang dapat diperoleh dan data yang dibutuhkan sedikit [5].

Pada penelitian ini akan dipelajari bagaimana analisis input-output dapat diimplementasikan untuk menganalisis keterkaitan setiap sektor ekonomi dari suatu matriks teknologi yang ditaksir menggunakan metode RAS, sehingga dapat diketahui sektor unggulan dari sistem perekonomian suatu wilayah pada tahun tertentu.

\section{B. Metodologi Penelitian}

Proses pengolahan data dalam penelitian ini diawali dengan melakukan penaksiran matriks teknologi menggunakan metode RAS kemudian akan dianalisis sektor unggulan pada perekonomian wilayah Kabupaten Tegal pada tahun 2020.

1. Penaksiran matriks teknologi dengan menggunakan metode RAS.

Tahapan melakukan penaksiran:

a. Pengelompokan sektor-sektor ekonomi wilayah Kabupaten Tegal.

Sektor-sektor ekonomi pada tabel input-output Kabupaten Tegal dengan matriks berukuran $54 \times 54$ akan dikelompokkan terlebih dahulu menurut keseragaman output dan data PDRB yang tersedia. Sehingga diperoleh matriks baru berukuran $17 \times 17$ dengan klasifikasi sektor seperti pada tabel 1. 
Tabel 1. Klasifikasi Sektor Ekonomi Kabupaten Tegal [6]

\begin{tabular}{|c|l|c|}
\hline Kode & \multicolumn{1}{|c|}{ Klasifikasi Sektor } & Simbol \\
\hline $01-16$ & Pertanian, Peternakan, Kehutanan, dan Perikanan & $\mathrm{A}$ \\
\hline 17 & Pertambangan dan Penggalian & $\mathrm{B}$ \\
\hline $18-32$ & Industri Pengolahan & $\mathrm{C}$ \\
\hline $33-34$ & Pengadaan Listrik dan Gas & $\mathrm{D}$ \\
\hline 35 & Pengadaan Air, Pengeloaan Sampah, Limbah dan Daur Ulang & $\mathrm{E}$ \\
\hline 36 & Konstruksi & $\mathrm{F}$ \\
\hline $37-38$ & Perdagangan & $\mathrm{G}$ \\
\hline $39-40$ & Transportasi dan Pergudangan & $\mathrm{H}$ \\
\hline $41-43$ & Penyedia Akomodasi & $\mathrm{I}$ \\
\hline 44 & Informasi dan Komunikasi & $\mathrm{J}$ \\
\hline $45-48$ & Jasa Keuangan dan Asuransi & $\mathrm{K}$ \\
\hline 49 & Real Estat & $\mathrm{L}$ \\
\hline 50 & Jasa Perusahaan & $\mathrm{M}$ \\
\hline 51 & Administrasi Pemerintahan & $\mathrm{N}$ \\
\hline 52 & Jasa Pendidikan & $\mathrm{O}$ \\
\hline 53 & Jasa Kesehatan dan Kegiatan Sosial & $\mathrm{P}$ \\
\hline 54 & Jasa Lainnya & $\mathrm{Q}$ \\
\hline
\end{tabular}

b. Menentukan jumlah input antara, jumlah permintaan antara, dan output.

Penentuan jumlah input antara, jumlah permintaan antara, dan output akan didasarkan pada nilai tambah bruto (NTB). Nilai tambah bruto setiap sektor diperoleh dari data Pendapatan Domestik Regional Bruto (PDRB).

c. Penaksiran matriks teknologi wilayah Kabupaten Tegal pada tahun 2020.

Matriks teknologi wilayah Kabupaten Tegal pada tahun 2020 akan diperoleh melalui langkah-langkah penaksiran menggunakan metode RAS. Matriks teknologi tahun awal $\left(A^{0}\right)$ yang digunakan merupakan matiks teknologi tahun 2016. Sementara total input antara, total permintaan antara dan total output diperoleh melalui hasil pendekatan dari nilai tambah bruto masing-masing sektor pada tahun 2020 . Perhitungan akan dihentikan sampai dipenuhi kriteria kekonvergenan yang telah ditentukan yaitu $\varepsilon=0.005$.

Dimana:

$$
A^{t}=R A^{0} S
$$

Dengan:

$A^{t}=$ matriks teknologi yang akan ditaksir pada tahun ke- $t$

$R=$ matriks penyesuaian jumlah permintaan antara

$A^{0}=$ matriks teknologi tahun awal

$S$ = matriks penyesuaian jumlah input antara

2. Analisis sektor unggulan daerah Kabupaten Tegal pada tahun 2020.

Menentukan sektor unggulan Kabupaten Tegal pada tahun 2020 didasarkan pada matriks teknologi hasil taksiran yang telah diperoleh pada langkah sebelumnya. Sektor unggulan dapat diketahui berdasarkan analisis keterkaitan yaitu keterkaitan ke belakang (backward linkages) dan keterkaitan ke depan (forward linkages) dengan melihat nilai indeks daya penyebaran dan indeks derajat kepekaan.

a. Keterkaitan ke belakang menyatakan daya penyebaran. Daya penyebaran merupakan dampak perubahan permintaan akhir pada suatu sektor terhadap total output [7]. Indeks daya penyebaran dihitung menggunakan rumus sebagai berikut:

$$
B L_{j}=\frac{\sum_{i=1}^{n} b_{i j}}{\frac{1}{n} \sum_{i=1}^{n} \sum_{j=1}^{n} b_{i j}}
$$


Dengan:

$B L_{j} \quad=$ indeks daya penyebaran sektor $j$

$\sum_{i=1}^{n} b_{i j}=$ jumlah kolom matriks kebalikan Leontief sektor $j$

$n \quad=$ banyaknya sektor

Jika nilai $B L_{j}<1$, berarti daya penyebaran sektor $j$ kurang dari rata-rata daya penyebaran seluruh sektor ekonomi. Nilai $B L_{j}=1$, berarti daya penyebaran sektor $j$ sama dengan rata-rata daya penyebaran seluruh sektor ekonomi. Dan ketika nilai $B L_{j}>1$, berarti daya penyebaran sektor $j$ sama dengan rata-rata daya penyebaran seluruh sektor ekonomi [6].

b. Keterkaitan ke depan menyatakan derajat kepekaan. Indeks derajat kepekaan dihitung menggunakan rumus berikut:

$$
F L_{j}=\frac{\sum_{j=1}^{n} b_{i j}}{\frac{1}{n} \sum_{i=1}^{n} \sum_{j=1}^{n} b_{i j}}
$$

Dimana:

$F L_{i} \quad=$ indeks derajat kepekaan sektor $i$

$\sum_{i=1}^{n} b_{i j}=$ jumlah baris matriks kebalikan Leontief sektor $i$

$n \quad=$ banyaknya sektor

Jika nilai $\boldsymbol{F} \boldsymbol{L}_{\boldsymbol{j}}<\mathbf{1}$, berarti derajat kepekaan sektor $\boldsymbol{i}$ kurang dari rata-rata derajat kepekaan seluruh sektor ekonomi. Nilai $\boldsymbol{F} \boldsymbol{L}_{\boldsymbol{i}}=\mathbf{1}$, berarti derajat kepekaan sektor $\boldsymbol{i}$ sama dengan rata-rata derajat kepekaan seluruh sektor ekonomi. Dan ketika nilai $\boldsymbol{F} \boldsymbol{L}_{\boldsymbol{i}}>\mathbf{1}$, berarti derajat kepekaan sektor $\boldsymbol{i}$ sama dengan rata-rata derajat kepekaan seluruh sektor ekonomi [6].

Berdasarkan indeks daya penyebaran dan indeks derajat kepekaannya, maka sektorsektor tersebut dapat dikelompokkan menjadi empat kelompok. Pengelompokan sektor tersebut dapat diilustrasikan pada tabel 2 .

Tabel 2. Pengelompokan Sektor Perekonomian Berdasarkan Keterkaitan ke Depan dan Keterkaitan ke Belakang [8]

\begin{tabular}{|c|c|c|c|}
\hline & \multicolumn{2}{|c|}{ Keterkaitan ke Belakang (Daya Penyebaran) } \\
\hline & & Rendah & Tinggi \\
\hline \multirow{2}{*}{$\begin{array}{l}\text { Keterkaitan ke Depan } \\
\text { (Derajat Kepekaan) }\end{array}$} & Tinggi & $\begin{array}{c}\text { Kelompok II } \\
\text { (Sektor sedang berkembang) }\end{array}$ & $\begin{array}{c}\text { Kelompok I } \\
\text { (Sektor Unggulan) }\end{array}$ \\
\hline & Rendah & $\begin{array}{l}\text { Kelompok IV } \\
\text { (Terbelakang) }\end{array}$ & $\begin{array}{l}\text { Kelompok III } \\
\text { (Sektor Potensial) }\end{array}$ \\
\hline
\end{tabular}

\section{Hasil Penelitian dan Pembahasan}

\section{Penaksiran Matriks Teknologi Wilayah Kabupaten Tegal pada Tahun 2020}

Perhitungan dilakukan dengan menggunakan program MATLAB sehingga diperoleh matriks teknologi hasil taksiran untuk tahun 2020 yang konvergen pada iterasi ke-36. Matriks tersebut disajikan pada gambar 1 berikut ini. 


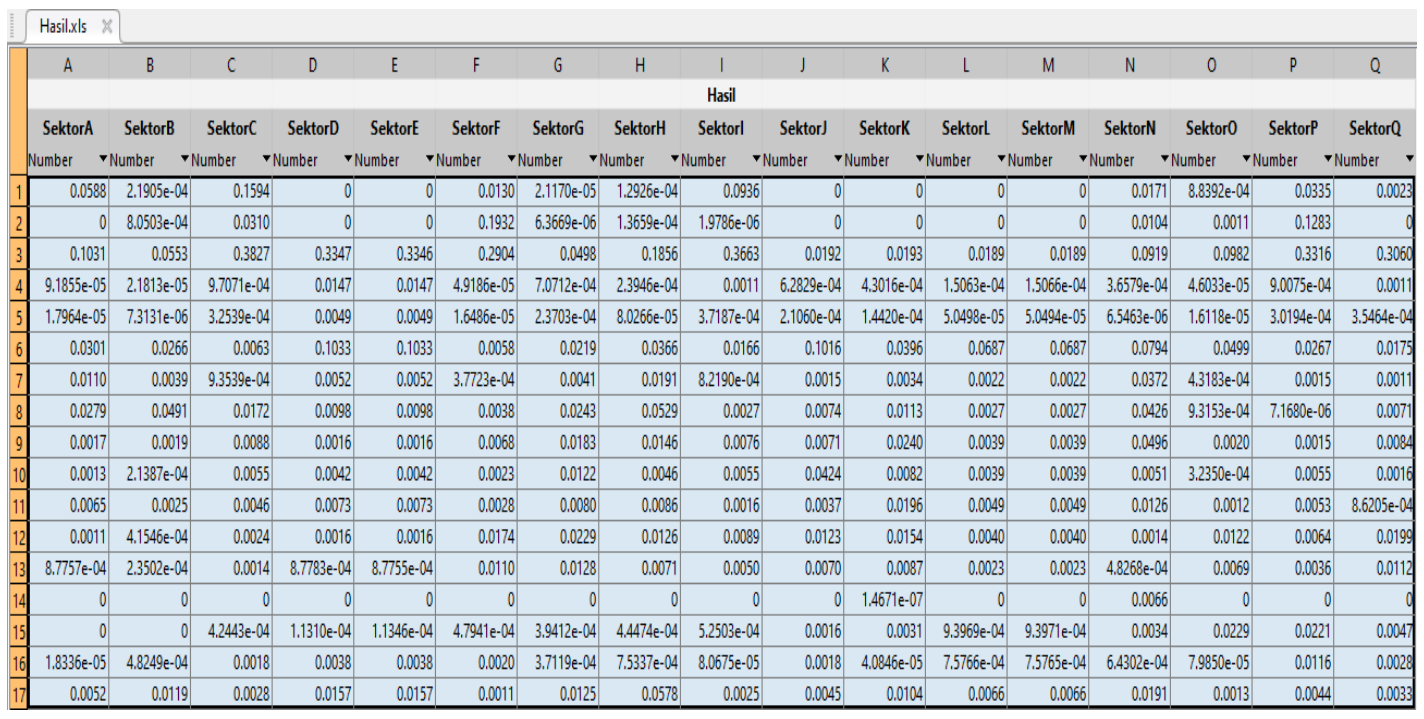

Gambar 1. Hasil Taksiran Matriks Teknologi Perekonomian Wilayah Kabupaen Tegal pada Tahun 2020

Menentukan Sektor Unggulan Wilayah Kabupaten Tegal pada Tahun 2020

Penentuan sektor unggulan wilayah Kabupaten Tegal pada tahun 2020 didasarkan pada matriks teknologi hasil taksiran yang telah diperoleh pada langkah sebelumnya. Sektor unggulan dapat diketahui berdasarkan analisis keterkaitan dengan melihat indeks daya penyebaran dan indeks derajat kepekaan.

Dengan menggunakan program MATLAB, diperoleh indeks daya penyebaran dan indeks derajat kepekaan masing-masing sektor di Kabupaten Tegal pada tahun 2020 yang disajikan pada tabel 3 berikut ini.

Tabel 3. Indeks Daya Penyebaran dan Indeks Derajat Kepekaan

\begin{tabular}{|c|c|c|}
\hline Sektor & Indeks Daya Penyebaran & Indeks Derajat Kepekaan \\
\hline A & 0.8768 & 1.4915 \\
\hline B & 0.7787 & 1.0516 \\
\hline C & 1.3254 & 4.2999 \\
\hline D & 1.2394 & 0.6253 \\
\hline E & 1.2393 & 0.6075 \\
\hline F & 1.1943 & 1.1966 \\
\hline G & 0.8005 & 0.6814 \\
\hline H & 1.0675 & 0.8969 \\
\hline I & 1.2199 & 0.7481 \\
\hline J & 0.8247 & 0.6977 \\
\hline K & 0.7698 & 0.6928 \\
\hline L & 0.7359 & 0.7198 \\
\hline M & 0.7359 & 0.6688 \\
\hline N & 1.0211 & 0.6027 \\
\hline O & 0.8298 & 0.6410 \\
\hline P & 1.2576 & 0.6270 \\
\hline Q & 1.0835 & 0.7514 \\
\hline
\end{tabular}

Berdasarkan indeks daya penyebaran dan indeks derajat kepekaan pada tabel 3, sektorsektor di Kabupaten Tegal dapat dikelompokkan menjadi empat kelompok, yaitu:

1. Kelompok I, yaitu kelompok sektor dengan indeks daya penyebaran dan derajat kepekaan tinggi, 
2. Kelompok II, yaitu kelompok sektor dengan indeks daya penyebaran rendah dan indeks derajat kepekaan tinggi,

3. Kelompok III, yaitu kelompok sektor dengan indeks daya penyebaran tinggi sementara indeks derajat kepekaannya rendah,

4. Kelompok IV, yaitu kelompok sektor yang memiliki indeks daya penyebaran dan indeks derajat kepekaan rendah.

Sektor-sektor ekonomi di wilayah Kabupaten Tegal pada tahun 2020 yang dikelompokan berdasarkan indeks daya penyebaran dan indeks derajat kepekaannya dapat dilihat pada tabel 4 .

Tabel 4. Pengelompokan Sektor Berdasarkan Keterkaitan ke Belakang dan Keterkaitan ke Depan

\begin{tabular}{|c|c|c|c|}
\cline { 3 - 4 } \multicolumn{2}{c|}{} & \multicolumn{2}{c|}{ Keterkaitan ke Belakang (Daya Penyebaran) } \\
\cline { 3 - 4 } \multicolumn{2}{c|}{} & Rendah & Tinggi \\
\hline Keterkaitan ke & Tinggi & Kelompok II & Kelompok I \\
Depan (Derajat & & A,B & C,F \\
\cline { 2 - 3 } Kepekaan) & \multirow{2}{*}{ Rendah } & Kelompok IV & Kelompok III \\
& & G,J,K,L,M,O & D,E,H,I,N,P,Q \\
\hline
\end{tabular}

Kelompok sektor dengan indeks daya penyebaran dan derajat kepekaan tinggi

Kelompok sektor pertama dapat dikatakan sebagai sektor-sektor unggulan (sektor kunci) atau sektor yang menjadi karakteristik perekonomian di wilayah Kabupaten Tegal pada tahun 2020. Sektor yang termasuk kedalam sektor kunci dinyatakan dalam tabel 5.

Tabel 5. Sektor dengan Indeks Daya Penyebaran (IDP) dan Indeks Derajat Kepekaan (IDK) Tinggi

\begin{tabular}{|c|c|c|c|c|}
\hline Simbol & Kode & Nama Sektor & Indeks Daya Penyebaran & Indeks Derajat Kepekaan \\
\hline C & $18-32$ & Industri Pengolahan & 1.3254 & 4.2999 \\
\hline F & 36 & Konstruksi & 1.1943 & 1.1966 \\
\hline
\end{tabular}

Berdasarkan hasil perhitungan, sektor industri pengolahan dan konstruksi memiliki keterkaitan ke belakang dan keterkaitan ke depan lebih dari rata-rata secara keseluruhan. Sehingga dua kelompok sektor ini sangat berpengaruh dan memiliki kemampuan yang besar untuk menggerakkan perekonomian wilayah Kabupaten Tegal.

Sektor-sektor unggulan tersebut memiliki indeks derajat kepekaan yang lebih besar dari indeks daya penyebarannya. Artinya, meskipun daya dorong kedua sektor terhadap sektor lain juga melebihi rata-rata secara keseluruhan, namun kecenderungan peran dari kedua sektor unggulan tersebut yaitu dalam menyerap output dari sektor lain. Output yang diserap oleh kedua sektor akan digunakan sebagai input dalam proses produksi. Hal ini menyebabkan meningkatnya pertumbuhan output pada kedua sektor yang kemudian akan mengakibatkan pertumbuhan ekonomi di wilayah Kabupaten Tegal.

\section{Kelompok sektor dengan indeks daya penyebaran rendah dan indeks derajat kepekaan tinggi}

Kelompok sektor kedua adalah kelompok sektor yang termasuk ke dalam sektor sedang berkembang. Sektor yang termasuk ke dalam kelompok sektor sedang berkembang merupakan sektor yang memiliki kemampuan tinggi dalam menyerap output dari sektor lain. Hal ini dapat dilihat dari indeks derajat kepekaan sektor yang lebih dari 1 atau di atas rata-rata derajat kepekaan secara keseluruhan. Berdasarkan pengertiannya, sektor yang memiliki indeks derajat kepekaan tinggi berarti memiliki keterkaitan ke depan yang tinggi atau memiliki ketergantungan yang tinggi terhadap sektor lain. Kelompok sektor ini dapat dilihat pada tabel 6 berikut ini. 
Tabel 6. Sektor dengan Indeks Daya Penyebaran Rendah dan Indeks Derajat Kepekaan Tinggi

\begin{tabular}{|c|c|l|c|c|}
\hline Simbol & Kode & \multicolumn{1}{|c|}{ Nama Sektor } & $\begin{array}{c}\text { Indeks Daya } \\
\text { Penyebaran }\end{array}$ & $\begin{array}{c}\text { Indeks Derajat } \\
\text { Kepekaan }\end{array}$ \\
\hline A & $1-16$ & $\begin{array}{l}\text { Pertanian, Peternakan, } \\
\text { Kehutanan dan Perikanan }\end{array}$ & 0.8768 & 1.4915 \\
\hline B & 17 & Pertambangan dan Penggalian & 0.7787 & 1.0516 \\
\hline
\end{tabular}

\section{Kelompok sektor dengan indeks daya penyebaran tinggi dan indeks derajat kepekaan} rendah

Kelompok sektor ketiga adalah sektor yang memiliki keterkaitan ke belakang yang tinggi tetapi keterkaitan ke depannya rendah. Sektor ini disebut sebagai sektor potensial karena memiliki daya dorong yang melebihi rata-rata keseluruhan sektor sedangkan kemampuan dalam menyerap output dari sektor lain berada di bawah rata-rata keseluruhan sektor.

Menurut hasil perhitungan, tujuh sektor termasuk ke dalam kelompok sektor potensial di wilayah Kabupaten Tegal pada tahun 2020. Sektor-sektor tersebut adalah sektor pengadaan listrik dan gas, sektor pengadaan air, pengelolaan sampah, limbah dan daur ulang, sektor transpotasi dan pergudangan, sektor penyedia akomodasi, sektor administrasi pemerintahan, sektor jasa kesehatan dan kegiatan sosial, dan sektor jasa lainnya. Indeks daya penyebaran dan indeks derajat kepekaan sektor-sektor potensial tersebut disajikan pada tabel 7.

Tabel 7. Sektor dengan Indeks Daya Penyebaran Tinggi dan Indeks Derajat Kepekaan Rendah

\begin{tabular}{|c|c|l|c|c|}
\hline Simbol & Kode & \multicolumn{1}{|c|}{ Nama Sektor } & $\begin{array}{c}\text { Indeks Daya } \\
\text { Penyebaran }\end{array}$ & $\begin{array}{c}\text { Indeks Derajat } \\
\text { Kepekaan }\end{array}$ \\
\hline D & $33-34$ & Pengadaan Listrik dan Gas & 1.2394 & 0.6253 \\
\hline E & 35 & $\begin{array}{l}\text { Pengadaan Air, Pengelolaan } \\
\text { Sampah, Limbah, dan Daur } \\
\text { Ulang }\end{array}$ & 1.2393 & 0.6075 \\
\hline H & $39-40$ & Transportasi dan Pergudangan & 1.0675 & 0.8969 \\
\hline I & $41-43$ & Penyedia Akomodasi & 1.2199 & 0.7481 \\
\hline N & 51 & Administrasi Pemerintahan & 1.0211 & 0.6027 \\
\hline P & 53 & $\begin{array}{l}\text { Jasa Kesehatan dan Kegiatan } \\
\text { Sosial }\end{array}$ & 1.2576 & 0.6270 \\
\hline $\mathrm{Q}$ & 54 & Jasa Lainnya & 1.0835 & 0.7514 \\
\hline
\end{tabular}

Kelompok sektor dengan indeks daya penyebaran dan indeks derajat kepekaan rendah Kelompok sektor terakhir adalah kelompok sektor yang memiliki keterkaitan ke belakang dan keterkaitan ke depan di bawah rata-rata secara keseluruhan. Berdasarkan hasil perhitungan, ada sebanyak enam sektor perekonomian di wilayah Kabupaten Tegal pada tahun 2020 dengan indeks daya penyebaran dan indeks derajat kepekaan rendah. Sektor-sektor tersebut dapat dilihat pada tabel 8.

Tabel 8. Sektor dengan Indeks Daya Penyebaran dan Indeks Derajat Kepekaan Rendah

\begin{tabular}{|c|c|l|c|c|}
\hline Simbol & Kode & \multicolumn{1}{|c|}{ Nama Sektor } & $\begin{array}{c}\text { Indeks Daya } \\
\text { Penyebaran }\end{array}$ & $\begin{array}{c}\text { Indeks Derajat } \\
\text { Kepekaan }\end{array}$ \\
\hline G & $37-38$ & Perdagangan & 0.8005 & 0.6814 \\
\hline J & 44 & Informasi dan Komunikasi & 0.8247 & 0.6977 \\
\hline K & $45-48$ & Jasa Keuangan dan Asuransi & 0.7698 & 0.6928 \\
\hline L & 49 & Real Estat & 0.7359 & 0.7198 \\
\hline M & 50 & Jasa Perusahaan & 0.7359 & 0.6688 \\
\hline O & 52 & Jasa Pendidikan & 0.8298 & 0.6410 \\
\hline
\end{tabular}


Keenam sektor tersebut dapat dikatakan sebagai sektor-sektor yang memiliki kemampuan yang rendah dalam menyerap output dari sektor lain maupun memberikan input dalam pertumbuhan produksi sektor yang lainnya.

\section{Kesimpulan}

Taksiran matriks teknologi Kabupaten Tegal tahun 2020 diperoleh dengan penentuan jumlah input antara, jumlah permintaan antara dan total output didasarkan pada data Nilai Tambah Bruto (NTB) Kabupaten Tegal tahun 2020. Proses RAS diterapkan dengan menggunakan matriks teknologi tahun 2016 sebagai tahun dasar sehingga diperoleh hasil taksiran matriks teknologi tahun 2020 yang memenuhi kriteria kekonvergenan pada iterasi ke-36. Berdasarkan hasil analisis terhadap taksiran matriks teknologi diperoleh bahwa sektor industri pengolahan dan sektor konstruksi merupakan sektor unggulan wilayah Kabupaten Tegal pada tahun 2020.

\section{Daftar Pustaka}

[1] B. P. B. d. Perbukuan, "KBBI," Kementerian Pendidikan dan Kebudayaan Republik Indonesia, 2019.

[2] Hajeri, E. Yurisinthae and E. Dolorosa, "Analisis Penentuan Sektor Unggulan Perekonomian di Kabupaten Kubu Raya," Jurnal Ekonomi Bisnis dan Kewirausahaan, vol. 4, no. 2, pp. 253-269, 2015.

[3] L. Masli and E. R. H, "Analisis Input-output Dalam Perencanaan Ekonomi," [Online]. Available: http://jsma.stan-im.ac.id/. [Accessed 21 Agustus 2021].

[4] Y. T. Sofia, "Menaksir Matriks Teknologi Tabel Input Ouput Kota Bandung Menggunakan Metode RAS," Statistika, vol. 15, no. 1, pp. 7-15, 2015.

[5] M. Lahr and L. de Mesnard, "Biproportional Techniques in Input-output Analysis: Table Updating and Structural Analysis," Economic System Research, vol. 16, no. 2, pp. 115-134, 2004.

[6] B. K. Tegal, "Tabel Input-output Kabupaten Tegal 2016," BPS Kabupaten Tegal, Tegal, 2018.

[7] I. W. Rafiqah, Darsono and J. Sutrisno, "Daya Penyebaran dan Derajat Kepekaan Sektor Pertanian dalam Pembangunan Ekonomi di Provinsi Jawa Tengah," AGRARIS, vol. 4, no. 1, pp. 51-58, 2018.

[8] R. Wahyuni and Maryunani, "Analisis Identifikasi Sektor Unggulan di Provinsi Jawa Timur Tahun 2010 (Pendekatan Input-output)," Universitas Brawijaya, Malang, 2013. 